MORAL, L. DEL y C. GIANSANTE (2000): “Constraints to Drought Contingency Planning in Spain: the Hydraulic Paradigm and the Case of Seville". Journal of Contingencies and Crisis Management, Special Issue "Contingency Planning for Water Security”, Blackwell, Oxford, Reino Unido, 2000, vol. 8, núm. 2, pp. 93-102

I.S.S.N: 0966-0879

\title{
Constraints to Drought Contingency Planning in Spain: the Hydraulic Paradigm and the Case of Seville
}

\begin{abstract}
Spain is at present equipped with an extensive hydraulic infrastructure, aimed at the correction of the temporal and spatial irregularity in the distribution of water resources. This infrastructure network, mainly focused on surface water, is embedded in a traditional hydraulic paradigm with technical, economic, socio-political and cultural implications.

This traditional water management perspective tends to view droughts as a circumstantial expression of a chronic water deficit, resulting from the so called structural deficit between water demand and the current water regulation capacity. This conceptualisation of the risk of drought leads to the predominance of structural responses to this hazard, the lack of consideration of uncertainty in the assessment of the available resources and the neglect of crisis planning. It can therefore be considered as one of the main obstacles to the development of a proactive approach for the management of droughts.

However, the water policy arena is currently very dynamic. This dynamism, which encompasses elements of both innovation and persistence of the traditional water paradigm, can be analysed through the example of the Seville water management system, characterised by a high risk of drought and the recent experience of several severe water crises.
\end{abstract}

\section{Introduction}

A long-standing tradition of water management exists in Spain, traditionally embodied by prestigious institutions such as the Tribunal de las Aguas in Valencia, which has been settling conflicts among irrigation farmers for more than 900 years. However, the present state of water planning in Spain is characterised by difficulties and barriers that obstruct the development and implementation of proactive planning to mitigate the effect of drought.

Why is it that Spain, formerly among the pioneers in the development of technological and institutional solutions for adequate management of water resources, has been severely affected by droughts in recent years? Why is Spain involved in a debate on the future of water planning, which never seems to get settled?

Changes are taking place, due to both internal and external factors. However, the question is, whether the system is developing beyond conventional planning to incorporate a framework for proactive planning, "which in advance develops a system of increased preparedness through appropriate coping mechanisms ... activated by the 
occurrence of drought and other uncertainties inherent in dry lands" (Bruins \& Lithwick, 1998: 5). Is the accumulated experience of previous droughts leading to a process of institutional learning, aimed to reduce the vulnerability of water management systems? If the answer is not completely affirmative then, what are the barriers that constrain the development of a more resilient system? Answering these questions could be the most useful contribution of this study.

\section{Drought and the Hydraulic Paradigm in Spain}

Aridity and drought have historically been a problem of the first order in Spain, due to the characteristics of its climate and hydrology. The Spanish climatologist Martín Vide has summarised these characteristics, as follows (Martín Vide, 1994, quoted in Moral and Sauri, 1999):

1. Modest rainfall amounts: nearly $50 \%$ of Spain receives less than $500 \mathrm{~mm}$ of precipitation per year;

2. High inter-annual rainfall variability: coefficients of variation may be as high as 40 $\%$ in certain areas;

3. High diversity of seasonal rainfall regimes;

4. High variability of seasonal rainfall patterns: in some years, the rainy season may be the dry season and vice-versa;

5. Occasional climatic anomalies: coincidence of drought periods in the generally wetter north of the Iberian peninsula with heavy rains in the drier south;

6. High daily and hourly rainfall intensities: precipitation of $100 \mathrm{~mm}$ in one day has a return period of 10 years or less in many areas;

7. Long rainless periods: Málaga recorded a sequence of 166 days without precipitation in 1953;

8. Existence of multiple 'rainy areas' and 'dry rain-shadow areas', due to intricate relief patterns

The resulting lack of water security led, already more than 100 years ago, to development planning to promote a radical transformation of Spain's water landscapes by means of hydraulic infrastructures. The 'war against drought', the correction of the temporal and spatial irregularity in the distribution of water resources - hydrological imbalances - has been a fundamental objective of the Spanish long lasting hydraulic paradigm water policy for more than a century. The theoretical basis (Regeneracionismo Hidráulico) and practical implementation of this policy, which constitutes a fundamental element in Spanish history, has been analysed on several occasions (see, for example, in English, Lopez-Gunn, 1996, Swyngendouw, 1999, del Moral \& Saurí, 1999 and del Moral, 1999).

In this context, water scarcity and irregularity are the core issue to be tackled by the water management. In some regions, such water scarcity is considered chronic and is called a structural deficit, result of the imbalance between water demand and available water resources. The latter are that fraction of natural water resources that can be used to satisfy demands, in the moment and place in which water is required. This notion leads to regulation, by which natural water resources (precipitation minus evapotranspiration) are converted into available water resources.

In Spanish hydrological planning, the assessment of available water resources is mainly focused on surface water reservoirs, that are supposed to store every year a total 
average of 39,145 million cubic meter (MCM) of water in the whole country. On the other hand, groundwater only accounts for $12 \%$ of the total available water resources in Spain (Table 1). Concerning the Guadalquivir river basin, in which Seville is located, an annual amount of about 2,819 MCM can be stored, which is nearly $85 \%$ of the total amount of available resources in this basin (Ministry of Environment, 1998).

Table 1. Available Water Resources in Spain and in the Guadalquivir river basin

\begin{tabular}{|l|c|c|c|c|}
\hline SOURCE & $\begin{array}{c}\text { Spain } \\
(\text { MCM/year })\end{array}$ & $\begin{array}{c}\text { Guadalquivir } \\
\text { River basin } \\
(\text { MCM/year })\end{array}$ & $\begin{array}{c}\text { Spain } \\
\%\end{array}$ & $\begin{array}{c}\text { Guadalquivir } \\
\text { River basin } \\
\%\end{array}$ \\
\hline Groundwater & 5,532 & 507 & 12,3 & 15.2 \\
\hline Reutilised water $(*)$ & 230 & 12 & 0.5 & 0.4 \\
\hline Desalinisation & 94 & -- & 0.2 & -- \\
\hline Reservoirs & 39,175 & 2,819 & 87 & 84.4 \\
\hline TOTAL & 45,034 & 3,338 & 100 & 100 \\
\hline
\end{tabular}

(*) Only directly reutilised water. Indirect reuse of return flows is not included Source: Ministry of Environment, 1998:205, quoted in Verges, 1999.

The Spanish hydrological assessments, water management reports and planning documents present the figures of reservoir regulation capacity with a deterministic terminology, despite the stochastic nature of surface flow, the limited duration of available hydrometric records (usually less than 50 years) and its lack of accuracy. Accordingly, the risk of drought is supposed to be integrated in the assessment of available resources, not as an uncertain phenomenon, but as a deterministic one, which can be regarded as nonsensical. The assessment of regulated water resources should encompass uncertainty in a more realistic way: "The amount of surface water resources can be calculated, with different degrees of probability, for each scenario of demand, considering the reliability of the hydrometric records utilised, the total reservoir capacity, dam operation rules, priorities policy, levels of guarantee of the different demands, etc. (López Arechavala, 1993:60). This is a key issue for the definition of the level of water security and the technical perception of risk. However, the perception of a water deficit is embedded in Spanish water policy as a more or less permanent situation. The whole water management system could be conceived as a drought management mechanism. But the results are far from satisfactory, due to the lack of accuracy of the deterministic estimates of water availability, in addition to the lack of control of different water users.

Spain has experienced the most severe water crises of all European countries in the past few years, notwithstanding the above hydraulic paradigm and the extensive water infrastructure system, which is equivalent to that in California. The drought period (1991-1995) caused problems to more than 11 million people, especially in the Eastern and Southern cities, who suffered from water supply restrictions and water quality problems in urban water supply systems. The agricultural sector also suffered during that period, due to reductions in their unitary water allowance, resulting in yield losses on a considerable part of the 3.4 million hectares of irrigation lands. Some of these lands were simply not irrigated. The economic losses and societal impacts were very high. Losses in the agricultural sector alone were estimated at 726,000 million pesetas (about US\$ 4,7 billion) (Consejo Económico y Social, 1996:22). 


\section{Structural imbalances and the neglect of contingency planning}

An interpretative hypothesis to explain the reasons for the development of these water crises, or the lack of institutional response and mitigation, can be based on two main contradictory elements: (1) The water management model comprehends the notions of scarcity and irregularity as central. (2) The perception of residual risk - the risk inherent to the system (Handmer \& Dover, 1996) - is low, while proactive contingency planning is absent. .

In other words, water management is based on the correction of hydrological irregularities, basically through a large-scale water infrastructure network. The estimates of regulated/available surface water resources include the existing historical records of flows - and thus, the repercussions of drought spells - but risk and uncertainty are disguised in average figures, presented in a deterministic manner, which is misleading.

Crisis situations are not contemplated as specific issues to be taken into account, but are considered as heightened expressions of general and permanent irregularity, that must be countered by further developing the water infrastructure system. The Spanish water management system does not use, as yet, the kind of drought definition, which, according to Hendrik Bruins, should include frequency and severity indexes and be "precise, regional and even specifically targeted at selected economic activities in order to be useful for proactive planning and government policy" (Bruins, 1997:81). Therefore, the water management system still lacks the basic characteristic of proactive planning that "takes such environmental uncertainties into consideration by preparing plans for ephemeral stochastic events, which become activated when such events (i.e. droughts) occur" (Bruins, 1997: 83).

This internal contradiction of the water management model is conditioned by the basic philosophy behind it, widely described in Spain and other countries as the traditional hydraulic paradigm. This water management model is based on water supply augmentation, with little consideration of the efficiency in water use and characterised by a highly subsidised water use. For instance, only $0.2 \%$ of the replacement value of publicly funded reservoirs is covered by tariffs (Verges, 1999). Clearly, this model systematically studied in Spain - is related to many other variables, which have been analysed through different theoretical frameworks. Tony Allan establishes a clear relationship between levels of economic development and different stages of hydraulic development in arid and semi-arid regions (Allan, 1996). Pierpaolo Faggi analyses the link between strategic irrigation projects and their legitimisation functions, especially in developing countries, through the 'territorial production for State reproduction' (Faggi, 1996). The Spanish sociologist Pérez Díaz has studied the organisational and institutional dynamics of the traditional engineering-driven supply augmentation approach, applying the concepts of policy community and issue network to the Spanish situation (Pérez Díaz et al., 1996). Recent proposals attempt to integrate the contributions of Mary Douglas' cultural theory with the New Institutionalism approach, focusing on different cultural paradigms and nature perception patterns, as explanatory devices to understand different ways to cope with risk (O'Riordan \& Jordan, 1998). The political dimension of the water issue, i.e. the consideration of those factors linked with struggles and conflicts between the different social groups, should not be overlooked (Kaika, 1999).

However, the basic mechanisms of Spanish water planning, which conceive scarcity and irregularity as structural geophysical features and neglect the need for specific contingency planning, enable us to understand the inherent difficulties within 
the Spanish water administration to cope with droughts. The experience of a water crisis, when it occurs, contributes to the justification and consolidation of the above mentioned water management model, based on the systematic regulating of the hydrological system. The general feeling of security, although conveyed to society in a contradictory way, is strengthened. Processes of water demand expansion are activated and reinforced, which reintroduce a level of vulnerability similar or even higher than the situation preceding the latest water crisis (Nevarez, 1996). Therefore, the emphasis on the expansion of the water resources system contributes to lower the general perception of vulnerability and thus increases the underlying risk, while failing to develop contingency planning and crisis management.

The above analysis may suggest a static, self-perpetuating negative state of affairs, but the current situation is in fact becoming very dynamic. Factors determining this dynamism include the surrounding economic and institutional changes, as well as the experience of the last important drought of 1991-95. This crisis initiated a process of reflection and institutional learning, which could develop towards a rationale of proactive planning. Ad hoc or reactive emergency mechanisms emerged at the time of the crisis, which, if maintained and integrated within the general water management, could be converted into proactive instruments, including institutional agreements and drought management programs. How consistently have these new mechanisms been integrated within the general management model and to what extent do they introduce changes in the routine practice of water management? These questions need to be explored.

Focusing on the urban water supply sector, many large towns in the country are presently debating the need to expand their sources of supply in order to face future contingencies of water scarcity or inadequate water quality. These urban centres include the two main metropolitan areas of the country, Madrid (4,8 million people) and Barcelona (4,2 million), as well as Saragossa (1,2 million) and Seville (1,3 million). Each city has its own specific system of water supply and ideas for expansion. Madrid proposes the construction of two new reservoirs to be built in "two of the last remaining stretches of river in the central part of the Iberian Peninsula, with clean waters and nonregulated flows" (Heras Hernández, 1998:20). Barcelona has expressed the need for a water transfer from the Rhone river (France) through the Pyrenees, which is being discussed (Barraqué, 1999). Saragossa has proposed the enlargement of an existing reservoir, presently assigned to irrigation purposes.

The water supply system of Seville will be discussed in detail in the following paragraphs. Seville has been severely affected by droughts in the past, while the risk of a new drought is probably the highest, as compared to the other urban centres. Given the frequency of recurrence of the drought crisis and the severity of its impacts, the case of Seville has become emblematic in the context of the debate on drought-coping strategies in Spain.

The case of the water supply system of Seville: coping with scarcity or setting the conditions for urban growth?

The metropolitan area of Seville has suffered three drought periods in the past three decades (1974-76, 1981-83 and 1991-95). Presently, a new dry year (1998-99) could be the beginning of a new dry spell. The impacts of these past droughts have been very severe in terms of reduced potable water quality and restrictions on supply (Table 1). 
Table 2. Water supply restrictions during the past three droughts in Seville

\begin{tabular}{|l|c|c|c|c|c|}
\hline & $\begin{array}{l}1974-76 \\
\text { Drought }\end{array}$ & \multicolumn{2}{|c|}{$\begin{array}{c}1980-83 \\
\text { Drought }\end{array}$} & \multicolumn{2}{c|}{$\begin{array}{c}1992-95 \\
\text { Drought }\end{array}$} \\
\hline & Date & Date & Date & Date & Date \\
\hline $\begin{array}{l}\text { I. Declaration of drought } \\
\text { (public awareness campaigns) }\end{array}$ & $09 / 74$ & $11 / 80$ & - & $02 / 92$ & $01 / 95$ \\
\hline $\begin{array}{l}\text { II. Prohibition of Municipal } \\
\text { Uses }\end{array}$ & $10 / 74$ & $01 / 81$ & - & $03 / 92$ & - \\
\hline $\begin{array}{l}\text { III. Water Rationing } \\
(<10 \text { hours of service) }\end{array}$ & $11 / 75$ & $02 / 81$ & $02 / 83$ & $09 / 92$ & $06 / 95$ \\
\hline $\begin{array}{l}\text { IV. Water Rationing } \\
(>10 \text { hours of service) }\end{array}$ & $01 / 76$ & $03 / 81$ & $09 / 83$ & $01 / 93$ & $11 / 95$ \\
\hline Normalisation & $12 / 76$ & $01 / 82$ & $01 / 84$ & $11 / 93$ & $01 / 96$ \\
\hline
\end{tabular}

Source: Bonneau, 1996; EMASESA, 1997.

Urban water demand has experienced an increase in the past three, due to a still growing population (about $0,7 \%$ annual growth), a new typology of urban development and large-scale events, such as the Expo 92, etc. (Table 2). On the other hand, unaccounted for water (UfW) rose from 32\% in 1975 to $36 \%$ in 1998 (national average $28 \%$, Verges, 1999).

In recent years, per capita water use has shown a decreasing trend, dropping from $426 \mathrm{lpd}$ in 1991 to about $300 \mathrm{lpd}$ at present, although the latter figure is still higher than the national average (265 lpd).

Table 3. Evolution of the water supply system of Seville

\begin{tabular}{|c|c|c|c|c|}
\hline & Supplied Population & $\begin{array}{l}\text { Abstracted Volume } \\
\text { (MCM) }\end{array}$ & $\begin{array}{l}\text { Billed Volume } \\
\text { (MCM) }\end{array}$ & $\begin{array}{l}\text { Per capita urban raw } \\
\text { water use (1/per./day) }\end{array}$ \\
\hline $1975 *$ & 779.000 & 102,3 & 69,9 & 359 \\
\hline $1976^{*}$ & 788.900 & 82,1 & 59,0 & 285 \\
\hline 1977 & 810.000 & 95,1 & 65,0 & 321 \\
\hline 1978 & 845.200 & 115,3 & 72,3 & 373 \\
\hline 1979 & 858.300 & 126,1 & 78,4 & 402 \\
\hline 1980 & 869.200 & 128,4 & 80,7 & 404 \\
\hline $1981 *$ & 880.200 & 82,2 & 59,4 & 255 \\
\hline $1982 *$ & 891.100 & 104,8 & 66,6 & 322 \\
\hline $1983 *$ & 908.400 & 99,2 & 64,5 & 299 \\
\hline 1984 & 915.100 & 109,2 & 68,5 & 326 \\
\hline 1985 & 922.900 & 116,3 & 75,6 & 345 \\
\hline 1986 & 925.900 & 126,9 & 81,5 & 375 \\
\hline 1987 & 952.900 & 137,8 & 87,9 & 396 \\
\hline 1988 & 1.023 .000 & 149,0 & 88,7 & 399 \\
\hline 1989 & 1.052 .200 & 153,0 & 93,4 & 398 \\
\hline 1990 & 1.072 .200 & 162,3 & 104,1 & 414 \\
\hline 1991 & 1.117 .400 & 173,8 & 107,3 & 426 \\
\hline 1992* & 1.143 .900 & 167,0 & 106,7 & 399 \\
\hline 1993* & 1.160 .800 & 133,3 & 87,5 & 314 \\
\hline 1994 & 1.179 .600 & 138,9 & 87,3 & 322 \\
\hline $1995 *$ & 1.198 .900 & 129,2 & 82,0 & 295 \\
\hline 1996 & 1.233 .588 & 134,0 & 83,3 & 297 \\
\hline 1997 & 1.295 .000 & 137,0 & 87,9 & 290 \\
\hline 1998 & $(* *)$ & 143,0 & 91,3 & $(* *)$ \\
\hline
\end{tabular}

(*) Years with water supply restrictions.

(**) No available data 
The sources of the Seville water supply system are the right-bank tributaries of the Guadalquivir river, located in the mountainous area to the north of the city of Seville (see map). The water quality of these rivers is very good, but their regime is, as usual, irregular. The large intra-annual and inter-annual variability, which is synonymous with the prevailing rainfall patterns in the region, has required the development of an extensive water regulation infrastructure. The water supply is mainly dependent on the Rivera de Huelva river, which has an average annual flow of about $325 \mathrm{MCM}$. The total reservoir capacity - due to five reservoirs already existing in the Rivera de Huelva catchment- is $448 \mathrm{MCM}$, which is higher by 38\% than the average natural water resources of the catchment $(325 \mathrm{MCM})$. This high volume of reservoir capacity is necessary to meet the water demand of Seville, as the average annual regulated flow is only 143 MCM, according to the Guadalquivir River Basin Hydrological Plan (Ministry of Environment, 1999). It is important to emphasise that the mentioned average annual regulated flow does not necessarily represent the actual volume available in the reservoirs each year, as the deterministic manner of data presentation would suggest.

Groundwater is currently barely used (less than $1 \%$ of total supply) in the water supply system of the metropolitan area of Seville, which makes this system highly dependent on surface water and thus particularly sensitive to climatic irregulatity. It is generally claimed - in official documents- that the reason for this limited use of groundwater resources in the Seville water supply system is its over-exploitation and contamination. However, according to the recently published Hydrogeological Atlas of Andalusia, there is an important potential for a greater use of groundwater resources, as a strategic source of water in situations of emergency and as a supplement to the water supply of Seville (Spanish Technological Institute for Hydrogeology and Mining, 1999). This issue is of crucial importance in the management of water scarcity and contingencies and, in fact, groundwater specialists, generally excluded from the water policy community, have been harshly criticising the dominant water policy, characterised by the lack of knowledge and neglect of aquifers and the consequent lack of control of their use.

The Guadalquivir river, which flows through the city of Seville, has estimated annual available resources of 3,332 MCM (2,819 MCM from reservoirs). With the existing infrastructure, the Guadalquivir river could meet the urban water supply of Seville (143 MCM/year). However, the main limitation to this option comes from the poor water quality of the river. Its treatment and use as potable water entails serious difficulties, even in a scenario of full implementation of the Urban Waste Water Directive (EC 91/271), due - amongst other - to diffuse pollution. At the end of the last drought, in 1995, even this potential source of low-quality water was not available. In 1995 the Guadalquivir basin reservoir system, with a total capacity of more than 6,500 MCM, was not able to supply the water volume required by the Seville water supply system. Because, during 1994, also a drought year, several hundred million cubic meter of water had been released from the reservoirs to irrigate agricultural fields, some cultivated with extensive crops. This is one of the clearest examples of the lack of foresight by the water management system, as well as a clear proof of the successful political pressure that can be applied by the agricultural sector vis-à-vis the water needs of the urban sector.

Finally, in the Sierra Morena mountain area, additional high-quality water resources can still be regulated in the Viar river - further away than the Rivera de 
Huelva river, but still easily accessible from Seville - through the construction of the Melonares dam. However, this potential solution would affect an area of high ecological value, designated as such according to nature protection legislation at the regional, national and European level. A reservoir already exists upstream of the site of the projected dam and supplies annually about $80 \mathrm{MCM}$ of water of pre-potable quality to the agricultural sector to irrigate 11,000 hectares, more than half of it cultivated with extensive herbaceous crops. Some water transfers from agricultural to urban use have been carried out here during past droughts.

Current consumers' water prices do not cover the full cost of provision and sanitation of water. This is due, on the one hand, to the subsidiation of raw water, via funding of the infrastructure for regulation, abstraction and transport of water. On the other hand, the facilities for waste water treatment and sanitation are subsidised. Besides this infrastructure is still insufficient to meet wastewater quality standards.

\section{Innovative experiences}

Changes can be observed in water management practices, which are either derived directly from the experience of previous droughts or from other independent social, political, economic and technological processes. Among these changes, the following are worth mentioning:

- Increased awareness of vulnerability. The confident diagnosis that existed before the previous drought contrasts sharply with the present evaluations. The situation of crisis during the 1991-1995 drought was amplified by the rapid growth of consumption in the second half of the 1980s, as can be inferred from Table 2. The situation was further aggravated by the conflicts between different administrations mainly national and regional - on official acknowledgement of the crisis. At present during the possible onset of another dry period - a more precautionary attitude can be observed, although annual water use has been allowed to grow from $135 \mathrm{MCM}$ in 1996 to 148 MCM in 1998, which may have been avoided.

- The change of collective water meters to individual household water meters could result in considerable savings in water use. This, in addition to the reduction in demand, resulting from an increased public awareness, can provide the basis for a long-term water conservation strategy (EMASESA, 1999, quoted in Kallis and Coccossis, 1999)

- Progress has taken place in the institutionalisation of water transfers from the Viar irrigation scheme to the domestic sector. This development is favoured by the intellectual and political atmosphere, as well as by the amendment of the 1985 Water Act, which prepares the ground for transactions between different users, especially in situations of drought.

- Current improvement in treatment systems for potable water, with investments of about 6,000 million pesetas (US\$ 37 million), would allow the utilisation of water from the Guadalquivir river in situations of drought with lower impacts on the drinking water quality than those experienced during the last drought.

- The first steps are taken towards a Drought Emergency Program, which envisages different measures to be adopted during drought. This contrasts with the atmosphere of secrecy, confusion and institutional confrontation, which reigned at the beginning of the last drought, in 1992. 


\section{Persistence of the basic elements of the traditional strategy}

The traditional water management discourse persists, despite these interesting innovations, because the above measures are viewed as possible and necessary, but insufficient to provide a solution to the problem of structural deficit. Therefore, the present regulation system must be expanded by the construction of a new reservoir. The emphasis, priority and energy currently devoted by the responsible water managers to the achievement of this strategic objective have important effects for the implementation of alternative solutions.

- The substitution of collective water meters by individual household meters is taking place at a very slow pace, despite the well-documented positive effect on the reduction of water use by about $25 \%$ per households involved.

- The water supply company maintains an ambivalent attitude concerning the wellknown persistence in time of reduced consumption after drought emergencies. In fact, its economic stability is dependent on water sales, which are affected by reduced demand. This reduction has been absorbed so far by water price increases.

- The key issue concerning water transfers from the Viar irrigation scheme has not been settled yet, despite some progress on the institutional aspects. The timing and sequence of water transfers must be defined to prevent farmers using all or most of the water before any transfer can be made to the city of Seville.

- A high degree of secrecy and confrontation is still maintained between distinct parts of the administration with different political affiliation. This shows the strong political content of water-related issues, due to economic interests, strategic development roles and the high symbolic value of water.

- The high subsidies generally available for water infrastructure schemes - mainly reservoirs - favours the persistence of the current water management model. On the one hand, it leads to extremely low raw water prices, which discourage water savings and reduction of leakage levels. On the other hand, it conditions the choice of the water utility concerning the most adequate responses to face water scarcity.

- Public relations and communication strategies are strongly influenced by the fact that priority is still assigned to the water infrastructure development model. Emotionally charged images - flooded fields during the rainy season, crackled soils during dry seasons - are systematically transmitted to society. The justification and strengthening of the need to carry out the planned infrastructure development measures derive from these images.

Therefore, it can be argued concerning Seville, as has been studied in other cases, that "the introduction of problems such as water scarcity becomes an extremely useful and powerful tool to construct a consensus around the continuation and application of a particular kind of developmental policy" (Kaika, 1999:99). This issue is crucial, because it introduces the following question: Are the root causes of the system's vulnerability addressed or do situations of drought promote further resource development works and network expansions? The analysis of the evolution of the Seville water supply system, as in the case of Santa Barbara (California), leads to the conclusion that "this type of planning chiefly provides surplus water for future development while making water users no safer from the threat of drought" (Nevarez, 1996:267).

It is clear that the water community, which dominates water policy in the Seville area (Giansante, 1999), is related to the vested interests of urban expansion and 
agricultural development, interwoven in the entrepreneurial network through privileged relations, tight social and cultural bonds. Both the urban and agricultural interest sectors are crucial. Seville is experiencing changes in the urban development model (suburbanisation), as in other European cities, that are likely to exacerbate the pressure on water resources (Kallis, 1999). While all institutions and communication media contribute to create an obsessive atmosphere of imminent drought, information is given at the same time - without establishing any link between the two elements - concerning the urban regrading of vast areas for residential purposes. These lands are part of large financial operations that constitute an outright development model with profound economic and political implications.

The basic dilemma for the medium-long term within the current urban development scenario is either the increased pressure on the water environment or the reallocation of water currently assigned to agricultural uses. The latter proactive strategy, a compensated water reallocation framework between irrigation farming and cities during periods of drought, would probably be the most flexible, economically efficient and environmentally sound solution. Farmers would start to change their productive strategy and release water resources for urban use with compensations of 6 pesetas $/ \mathrm{m}^{3}\left(0.0375 \$ / \mathrm{m}^{3}\right)$, according to a very exhaustive recent study, confirmed by empirical practice during 1994 (Sumpsi et al. 1998). Although the social and spatial implications of such transfers should be carefully evaluated, there is a general agreement on the great potential of these transactions (Giansante, Babiano \& Moral, forthcoming). However, the establishment of such a solution is hindered by the strong political and cultural forces of the agricultural lobby and by other institutional arrangements. These are the cultural, social and economic factors, which constitute the basis of the traditional engineering-driven supply augmentation approach. Amongst the economic factors, the current subsidising system, which favours large scale water regulation infrastructure, is particularly important.

\section{Difficulties for the continuation of the traditional water development model}

The traditional water community approach also faces difficulties, notwithstanding the above mentioned elements of inertia. The general difficulties faced by the Seville water supply system to continue handling risk with the traditional approach of increasing supply through successive water resource development projects are as follows:

- Increasing costs of infrastructure, despite the subsidiation system in force.

- Greater social (impacts on local population) and environmental constraints

- Increased competition for water between different water use sectors.

- Development of a general atmosphere, which is favourable to solutions that incorporate "scarcity indicators" This favourable atmosphere would include both the provision for full cost recovery and economic analysis of water uses made in the EU Framework Water Directive and the market mechanisms, introduced by the recent amendments (December 1999) to the 1985 Water Act. As regards the Seville water supply system, the introduction of full cost recovery prices would probably change the current priorities concerning the measures to cope with the water deficit and to manage the risk of drought.

- The re-scaling of the decision-making process. In our case, re-scaling occurs in both directions: downwards (regional governments) and upwards (European Union). This trend is not only related to decisions taken within the water management system, but 
depends rather on the context. It does not help but rather hinders the objectives of the traditional water community, which is basically focussed on infrastructure development projects. The European Union has become a fundamental actor on the scene, as a consequence of this re-scaling trend. The EU represents the only source of resistance to the traditional water policy community, along with the weak environmental organisations and the even weaker political expression of the nature conservation agenda at the local level.

The mentioned difficulties become especially explicit in the case of the project for the construction of the Melonares dam on the Viar river to increase the resources of the Seville water supply system. This project, originally conceived in 1972, has faced several obstacles that prevented its approval until today. The environmental assessment process started in 1990 and ended in 1997, with a positive Environmental Impact Assessment declaration in case it was proved that $t$ "no alternative options for the water supply of Seville" existed. The latter clause has stimulated a rather limited social debate. Since 1997, the main difficulties faced by the project concern the approval by the European authorities of funding and environmental compensation measures, which led to several meetings between EU technical staff and representatives of national, regional and local authorities. Confusion arose concerning the exact role of the EU in the decision-making process. The socialist parliamentary group (currently in the opposition) demanded on 20th July 1999 from the conservative government the financial resources to fund the above scheme without waiting for the approval for funding by DGXVI of the European Commission (for Regional Policy and Cohesion). The Ministry of the Environment responded by stating that the approval by DGXVI was needed: "Although funding of this project has already been included in the State Budget, Spain cannot start the works until we are sure that the commitments we made concerning environmental protection are fulfilled" (ABC newspaper, 21 July 1999).

The role of the EU is centred around its responsibility on environmental issues, as related to environmentally protected areas that would be affected by the construction of the new reservoir. However, an additional role played by the EU is linked with the grant of a subsidy to partially (75\%) cover the costs of this water regulation scheme, by means of the Cohesion Funds, for which less developed regions of the EU, such as Andalusia, are eligible. This double role of the EU has created some confusion, which favours the process of separating the general public from the information and underlying debate. These results are similar to those described elsewhere in another context: "making the project less politically visible, rendering it technical, evading public accountability, and ultimately excluding public opposition" (Nevarez, 1996: 253).

\section{Conclusions}

In Spain, the deceptive conceptualisation and management of droughts, which is characteristic of the traditional hydraulic paradigm, is still in force, though in a profound state of crisis and under increasing social debate. This paradigm, which is the expression of the hydraulic mission, has produced a radical change during the past 100 years in the water landscape of the country, by means of a profound temporal regularisation and spatial redistribution of water resources. The spatial development model of the whole country, including the agricultural, urban and industrial sectors, is based on this social reconstruction of the water environment. However, this mighty system aimed at a structural hydraulic equilibrium has neglected risk assessment and 
contingency planning. The system has proved to be extremely vulnerable, as a result. The model, which is based on the systematic increase of water regulation capacity, expressed in deterministic values, has discouraged the perception of residual risk. The model has promoted the expansion of demands and the subsequent reproduction of vulnerability, even increasing it. Economic, technological, demographic or climatic uncertainty scenarios are almost completely absent in this context.

The difficult experience of the last two drought periods, along with other changes in the arena of water politics, has promoted the appearance of some elements of proactive planning. The stabilisation and institutionalisation of these elements would lead to the configuration of a new water management system. However, this potentially positive trend is resisted by conventional planning strategies. The traditional water management system still shows great inertia, supported by a network of deeply rooted interests, political strategies, organisational routines and cultural values, despite the increasing difficulties it faces.

The application of this analytical framework to the water supply of the metropolitan area of Seville, shows that, also in this case, problems have not been solved. Elements of persistence of the traditional paradigm coexist with other elements of innovation, resulting both from the experience of previous droughts and from other socio-political and economic processes. The elements of innovation include an increased awareness of the system vulnerability, the inclusion in the discourse - and, partially, also in the practice - of the water utility of some demand management measures (e.g. installation of individual household meters) and the first steps towards the institutionalisation of an emergency drought plan and, possibly, towards some kind of institutionalisation of contingency water transfer from agriculture to urban supply.

However, the conventional planning approach, albeit with increasing difficulties, still persists and is characterised by the predominance of a supply augmentation strategy - still supported by high subsidies - and a high degree of secrecy and confrontation in the water debate. This is particularly evident in the current debate concerning the supply augmentation option, put forward by the water utility. Thus, these elements of inertia still hinder the adequate development of new, integrated planning approaches, which comprise contingency planning and crisis management mechanisms for periods of severe drought.

\section{Note}

1. The formulation of this article was inspired by the discussions held in the context of the project Social and Institutional Responses to Climate Change and Climate Hazards (DGXII, European Union), co-ordinated by Thomas Downing and Karen Bakker (University of Oxford).

\section{References}

Allan, J.A. (1996), 'Water and development: relevance to water allocation and management policy', in Allan, J.A. \& Radwan, L. (Eds.), Perceptions of the values of water and water environments, University of London-SOAS Water Issues Group, London, pp.107-110. 
Barraqué, B. (Coord.)(1999), Les demandes en eau en Catalogne: perspective europeenne sur le project d'aqueduc du Rhone a Barcelone, Raport final, Ministère de l'Environnement-Direction de l'eau, Paris.

Bruins, H. J. (1997), 'Natural Drought and Human-made Drought in Israel: Proactive Planning and Interactive Management', III Conferencia Internacional Gestión de la Sequías. Experiencias y Lecciones para la Palnificación, Iberdrola Instituto Tecnológico, Valencia, p. 65-88.

Bruins, H.J. \& Lithwick, H. (1998), The Arid Frontier. Interactive Management of Environment and Development, Kluwer Academic Publishers, Dordrecht.

Faggi, P-P. (1996), 'Productive and strategic values in drylands irrigation in developing countries: notes towards sustainable development', in Allan, J.A. \& Radwan, L. (Eds.), Perceptions of the values of water and water environments, University of London-SOAS Water Issues Group, London, pp. 113-116.

Giansante, C. (1999), In-depth analysis of relevant stakeholders: Guadalquivir River Basin Authority, SIRCH project, Seville, 18 March 1999.

Giansante, C., Babiano, L \& Moral, L. (forthcoming), 'L'evolution des modalités d'allocation des resources en eau en Espagne', Revue d'Economie Méridionale (REM), Number 2, University of Montpellier, June 2000.

Handmer, J. \& Dover, S. (1996), 'A Typology of Resilience: Rethinking Institutions for Sustainable Development', Industrial and Environmental Crisis Quarterly, Number 9, pp. 482-511.

Heras Hernández, F. (1998), ¿Más agua para Madrid? Datos y reflexiones para un debate necesario, Bakeaz, Nueva Cultura del agua, Bilbao.

Kaika, M. (1999), '170 days that shook Athens. The social construction of water scarcity and the political ecology of a dam construction: censored and uncensored stories', in Conference on Sustainability, Risk and Nature: the Political Ecology of Water in Advanced Societies, University of Oxford, School of Geography, Oxford, pp. 93-103.

Kallis, G. and Coccossis, H. (1999), 'Sustainable Use of Water in Metropolitan Areas: An Integrated Framework for Policy Analisis', in Conference on Sustainability, Risk and Nature: the Political Ecology of Water in Advanced Societies, University of Oxford, School of Geography, Oxford, pp. 127-146.

López Arechavala, G. (1993), 'Datos de base para los estudios hidrológicos', in Instituto Tecnológico Geominero de España, Las aguas Subterráneas. Importancia y perspectivas, Madrid, pp. 49-70.

López-Gunn. E. (1996), 'Spanish water supply and demand management: the case of water transfers', in Howsam, P \& Carter, R.C. (Eds.) Water Policy: Allocation and management in practice, E \& FN Spon, pp. 78-86.

López, I. (1999) Más caro que el agua. Consumerismo, Revista de los Consumidores Andaluces, FACUA, nº0, September-October 1999, pp.xxx

Ministry of Environment (1998), Libro Blanco del Agua en España, Madrid.

Ministry of Environment (1999), Orden del 13 de agosto de 1999, Boletín Oficial del Estado, Number 205, 27/8/1999.

Moral, L. (1996), 'The debate on financial and economic regulation of water in contemporary hydrological planning in Spain', in Allan, J.A. \& Radwan, L. (Eds.), Perceptions of the values of water and water environments, University of LondonSOAS Water Issues Group, London, pp. 37-45.

Moral, L, (1999), 'Social and political conflict in the redefinition of the water management model in Spain', in Conference on Sustainability, Risk and Nature: the Political 
Ecology of Water in Advanced Societies, University of Oxford, School of Geography, Oxford, pp. 82-93.

Moral, L. and Saurí, D. (1999), 'Changing Course. Water Policy in Spain', Environment, Volume 41, Number 6, July-August, pp. 12-36.

Naredo, J.M. (1998), 'Enfoques económicos y ecológicos en la encrucijada actual de la gestión del agua en España', en Arrojo, P. \& Naredo, J.M., La gestión del agua en España y California, Bakeaz, Nueva Cultura del agua, Bilbao, pp. 153-185.

Nevarez, L. (1996), 'Just wait until there's a drought: mediating environmental crises for urban growth', Antipode, Volume 28, Number 3, pp. 246-272.

O'Riordan, T. and Jordan, A. (1999), 'Institutions,climate change and cultural theory: towards a common analytical framework', Global Environmental Change, Number 9, pp. 81-93.

Pérez-Díaz, V., Mezo, J. \& Alvárez-Miranda, B. (1996), Política y economía del agua en España, Círculo de Empresarios, Madrid.

Spanish Technological Institute for Hydrogeology and Mining (1999), Atlas Hidrogeologico de Andalucía. Andalusian Department of Public Works and Transport, Regional Government of Andalusia. Seville.

Sumpsi Viñas, J.M., Garrido, A. et al. (1998), Economía y Política de Gestión del Agua en alAgricultura, Mundi-Prensa, Madrid.

Swyngedouw, E. (1999), 'Modernity and Hybridity: Regeneracionismo, the Production of nature and the Spanish Waterscape, 1890-1930', Annals of the Association of American Geographers, Volume 89, Number 3, pp. 443-465.

Vergés, J. (1999), 'Full Cost Pricing of Water in Spain'. Hydropôle 99, La politique europénne de l'eau, 17 June 1999, Marseille (France). 